\title{
Effects of Variable Calcium and Manganese on the Enzyme, Nucleotide, and Nutrient Constituents of Sugarcane Grown by Sand Culture
}

\author{
Alex G. Alexander and George Samuels ${ }^{1}$ \\ INTRODUCTION
}

Until recently the roles of calcium $(\mathrm{Ca})^{2}$ and manganese $(\mathrm{Mn})$ in sugarcane culture have been studied from the soils standpoint. Low available Ca and high Mn is normal for many acid tropical soils (1). ${ }^{3}$ Lime applied to such soils usually suppresses uptake of $\mathrm{Mn}$, plus iron and aluminum, by raising soil $\mathrm{pH}$. Thus the application of $\mathrm{Ca}$ as lime to acid soils has increased the Ca content of cane, while the Mn content declined (15,17). A significant question is whether $\mathrm{Ca}$ itself can suppress $\mathrm{Mn}$ uptake independently of $\mathrm{pH}$ changes.

More difficult to define are the effects of $\mathrm{Ca}$ and $\mathrm{Mn}$ which involve more than changes in elemental content of the plant. Ca-deficient plants have been found to contain significantly more sucrose than those given adequate $\mathrm{Ca}$ in sand culture (14,22). Application of Ca-compounds to cane fields has led to greater sugar yields, apparently by increased tonnage rather than higher sucrose values $(15,20)$. Recently the sucrose-hydrolyzing enzyme invertase was shown to be activated in vitro by Mn (7). Later work revealed that amylase also is activated by Mn, thereby confirming an unusually significant role of this element in the regulation of carbohydrate-hydrolyzing reactions (8).

It has been shown that acid phosphatases and invertases are markedly suppressed in cane by high Mn supplied in sand culture (23). The same study showed that tyrosinase, a probable terminal oxidase of cane, may be either retarded or activated by high Mn, depending upon concurrent supplies of Si. With regard to $\mathrm{Ca}$, a $\mathrm{Ca} \times$ Mo interaction was discovered which blocks the normal capacity of Mo to suppress phosphatases (6). As a consequence of high $\mathrm{Ca}$, enzymes such as ATP-ase and glucose-1-phosphatase can more readily hydrolyze essential intermediates of sucrose synthesis. Such nutrient functions cannot be discussed in terms of elemental content since the quantities actually involved with enzymes are but a tiny fraction of the total absorbed.

${ }^{1}$ Associate Plant Physiologist and Agronomist, respectively, Agricultural Experiment Station, University of Puerto Rico, Río Piedras, P.R.

${ }^{2}$ Abbreviations: Molar, M; Uridine diphosphate glucose, UDPG; ultraviolet; U.V.; trichloroacetic acid, TCA.

${ }^{3}$ Italic numbers in parentheses refer to Literature Cited pp. 250-1. 
We suspect, however, that $\mathrm{Ca}$ and $\mathrm{Mn}$ affect sucrose production by means other than nutrient balance and enzyme regulation. This belief was recently strengthened when $\mathrm{Mn}$ and $\mathrm{Fe}$ were found to alter the number plus the concentration of rare sugars in cane-leaf extracts ${ }^{4}$. It is also felt that nucleotide content might be a significant factor in determining sucrose potential. To this end, nucleotide studies are in progress here $(12,13)$ and have been extended to the present investigations of $\mathrm{Ca}$ and $\mathrm{Mn}$ roles.

The work reported herein had three objectives: 1 , To determine whether Ca could modify the rate of Mn uptake; 2 , to determine the main effects and interactions of $\mathrm{Ca}$ and $\mathrm{Mn}$ on specific enzymes; and 3, to study the effects of variable $\mathrm{Ca}$ and $\mathrm{Mn}$ on the sugar and nucleotide content of sugarcane.

\section{MATERIALS AND METHODS}

\section{GROWTH AND PREPARATION OF PLANT MATERIALS}

All plants were grown in the greenhouse using $\mathrm{HCl}$-washed silica shot in glazed, 2-gallon containers. One liter of a balanced nutrient solution ${ }^{5}$ was supplied daily to each container until the plants were 16 weeks of age. Treatments were initiated at this time and continued for 14 weeks. Two levels of $\mathrm{Ca}$ and three of $\mathrm{Mn}$ were given in factorial combination. Calcium was provided at rates of 0 and 10 meq./liter, and $\mathrm{Mn}$ at 0,10 , and 100 p.p.m. The treatments were replicated three times in a completely randomized greenhouse design.

A single harvest was taken when the plants were 30 weeks of age. Leaves +1 to +4 were frozen, lyophilized, and ground to pass a 60 -mesh screen. Enzyme and sugar extracts were prepared in accordance with methods previously described (2).

\section{LABORATORY ANALYSES}

Sucrose was determined in water extracts by the method of Cardini et al. (16). Phosphatase was assayed according to methods described earlier (2), as was amylase (8), peroxidase (10), and tyrosinase (11). Protein was measured colorimetrically by the technique of Sutherland et al. (25), and enzyme activity was then computed as specific activity, i.e., activity units per milligram of protein.

Acid-soluble nucleotides were extracted from powdered leaf tissue with

${ }^{4}$ Unpublished data.

${ }^{5}$ Nutrient concentrations, expressed as milliequivalents per liter, were provided as follows: Nitrate, 10 ; phosphate, 6 ; potassium, 5 ; calcium, 3 ; magnesium, 2 ; and sulfate, 2. Micronutrients, expressed as parts per million, were supplied as follows: Boron, 0.05, copper, 0.02; manganese, 0.50; zinc, 0.05, molybdenum, 0.01; and iron, 1.0. 
10-percent TCA at $22^{\circ} \mathrm{C}$. Tissue debris was removed by centrifuge and washed with one bed-volume of 10-percent TCA. TCA was removed by repeated extraction with ethyl ether, the latter containing a small amount of water to retard peroxide formation. Residual ether was eliminated under reduced pressure at room temperature. The extract was then chromatographed on anion-exchange columns, employing the resin Dowex 1-X4, 50-100 mesh, prepared by the formate method of Hurlbert, et al. (19).

A 4-ml. sample was slowly washed on to the column with water and eluted with $1 \mathrm{M}$ sodium formate in $2 \mathrm{~N}$ formic acid, $\mathrm{pH} 2.9$, and $6 \mathrm{~N}$ formic acid, $\mathrm{pH} 0.6$, in that order. One-milliliter fractions were collected and appropriate dilutions were analyzed at 260 and $275 \mathrm{~m} \mu$ with a Beckman Model DB spectrophotometer. Peak U.V.-absorbing fractions were combined and dried under reduced pressure, or frozen in thin layers and lyophilized. Samples of the U.V.-absorbing solutions were assayed for total reducing sugar by the dinitrosalicylic acid method of Summer (24), following a 100-minute hydrolysis in $6 \mathrm{~N} \mathrm{HCl}$ at $100^{\circ} \mathrm{C}$. Total nucleotide content was estimated in terms of O.D.260 units. A reference solution was prepared containing the monophosphates of adenosine, uridine, and cytidine, each at the rate of $0.01 \mu$ mole per milliliter. One O.D.260 unit gave an O.D. reading of 0.22 at $260 \mathrm{~m} \mu$.

Paper chromatographic studies were conducted both with clarified leaf extracts and concentrated U.V.-absorbing samples. The descending technique was run in one dimension with Whatman No. 1 chromatography paper, employing the solvents ethanol-0.3M ammonium acetate, 2.5:1, or butanol-pyridine-water, $6: 4: 3$. Ten to twenty $\lambda$ ( $\mu$ liters) of cane preparations were usually spotted plus $2-\lambda$ volumes of 0.10 -percent solutions of reference nucleotides. Dried chromatograms were scanned with a Chromato-Vue apparatus equipped with both long-wave and short-wave U.V. lamps. Sugars were located by staining with the silver nitrate dip technique (18).

\section{RESULTS AND DISCUSSION}

\section{EFFECTS OF CA AND MN ON NUTRIENT UPTAKE}

Leaf analyses for N, P, K, and Fe revealed no differences between treatments, and, as expected, Ca was significantly higher in plants receiving the higher Ca supply (table 1). To explain the fact that the $\mathrm{Ca}$ content did not vary greatly between the 0 and 10 meq./liter treatments, one must remember that all plants had received adequate Ca levels during their first 4 months of growth, and none was considered to be Ca-deficient. Manganese content increased with progressively higher Mn supply. More important is the fact that high Ca (10 meq./liter) enhanced Mn uptake, 
giving almost 100 p.p.m. more Mn than the zero-Ca treatment (table 1). It therefore appears likely that lower Mn from soils is attributable to $\mathrm{pH}$ factors rather than the $\mathrm{Ca}$ of lime or silicon-bearing materials.

It is interesting to note that $\mathrm{Si}$ content was suppressed by high $\mathrm{Mn}$ (100 p.p.m.), and that this occurred only when Ca was low. Si suppression by $\mathrm{Mn}$ appears at a glance to be at variance with well-defined previous observations (2S) which showed that increasing Mn supply caused significant Si increases in the leaf blade. We therefore feel that $\mathrm{Ca}$ is the critical factor which may have interfered with a $\mathrm{Mn} \times$ Si relationship.

TABLE 1.-Effects of variable calcium and manganese on the leaf-nutrient and silicon content of sugarcane grown in sand culture ${ }^{1}$

\begin{tabular}{|c|c|c|c|c|c|c|c|c|}
\hline \multicolumn{2}{|c|}{$\begin{array}{c}\text { Treatment }- \\
\text { Ca meq. } / \text { liter } \times \text { Mn p.p.m. }\end{array}$} & $\mathrm{N}$ & $\mathrm{P}$ & K & $\mathrm{Ca}$ & $\mathrm{Si}$ & Mn & $\mathrm{Fe}$ \\
\hline & & Percent & Percent & Percent & Percent & percent & P.p.m. & P.p.m. \\
\hline 0 & 0 & 1.06 & $\begin{array}{r}0.28 \\
26\end{array}$ & 3.6 & $\begin{array}{r}0.23 \\
21\end{array}$ & $\begin{array}{r}0.49 \\
\end{array}$ & $\begin{array}{r}23 \\
135\end{array}$ & $\begin{array}{r}70 \\
66\end{array}$ \\
\hline \multirow[t]{2}{*}{0} & $\begin{array}{r}10 \\
100\end{array}$ & $\begin{array}{l}1.02 \\
1.08\end{array}$ & $\begin{array}{l}.20 \\
.26\end{array}$ & 3.6 & .21 & .28 & 680 & 86 \\
\hline & Mean & 1.05 & 0.27 & 3.6 & 0.22 & 0.40 & 279 & 74 \\
\hline 10 & 0 & 1.02 & 0.25 & 3.4 & 0.33 & 0.51 & 135 & 88 \\
\hline 10 & 10 & .92 & .27 & 3.4 & .31 & .32 & 156 & 85 \\
\hline \multirow[t]{2}{*}{10} & 100 & 1.10 & .25 & 3.2 & .30 & .48 & 825 & 69 \\
\hline & Mean & 1.01 & 0.26 & 3.3 & 0.31 & 0.44 & 372 & 81 \\
\hline
\end{tabular}

${ }^{1}$ Each figure represents the computed mean of 3 replicates.

\section{EFFECTS OF CA AND MN ON SUCROSE CONTENT AND ENZYME ACTIVITY}

As anticipated from earlier work (13,21), plants receiving zero Ca bore the highest leaf-sucrose content (table 2). This was true when Mn was supplied at 0 or 10 p.p.m., but 100 p.p.m. Mn eliminated the sucrose differences. High Mn accomplished this by suppressing sucrose to a level comparable to that obtained with high Ca. Since high Mn did not increase $\mathrm{Ca}$ content (table 1) we suspect that $\mathrm{Mn}$ has substituted for high $\mathrm{Ca}$ participating in reactions less directly related to sugar formation.

In order to study more closely the leaf-sugar constituents, extracts were chromatographed and stained. Figure 1,A illustrates chromatographed samples from one complete $\mathrm{Ca} \times \mathrm{Mn}$ replicate. Clearly evident for each treatment are masses of glucose and fructose, with sucrose obviously varying in response to $\mathrm{Ca}$ and $\mathrm{Mn}$. Trace amounts of the trisaccharide raffinose (glucose-glucose-fructose) appear in each extract. No evidence 
of melezitose (glucose-fructose-glucose) was found, nor was ribose or UDPG present in any preparation.

The enzymes amylase and peroxidase were strikingly affected by varying $\mathrm{Ca}$ and Mn levels (table 2, and Fig. 1,B). Mn suppressed amylase, but

TABLe 2.-Mean values for leaf-sucrose content and enzyme activity of sugarcane supplied with variable calcium and manganese in sand culture ${ }^{1}$

\begin{tabular}{|c|c|c|c|c|c|c|c|c|}
\hline \multicolumn{5}{|c|}{ Sucrose } & \multicolumn{4}{|c|}{ Amylase } \\
\hline Treatment & $\mathrm{Mn}_{0}{ }^{2}$ & $\mathrm{Mn}_{10}$ & $\mathrm{Mn}_{100}$ & Mean & $\mathrm{Mn}_{0}$ & $\mathrm{Mn}_{10}$ & $\mathrm{Mn}_{100}$ & Mean \\
\hline $\mathrm{Ca}_{0}$ & 103 & 117 & 84 & 101 & 45.3 & 37.9 & 23.4 & 35.5 \\
\hline $\mathrm{Ca}_{10}$ & 73 & 79 & 84 & 79 & 19.6 & 20.4 & 22.4 & 20.9 \\
\hline Mean & 88 & 98 & 84 & & 32.4 & 29.1 & 23.1 & \\
\hline \multicolumn{5}{|c|}{ Peroxidase } & \multicolumn{4}{|c|}{ Tyrosinase } \\
\hline Treatment & $\mathrm{Mn}_{0}$ & $\mathrm{Mn}_{10}$ & $\mathrm{Mn}_{100}$ & Mean & $\mathrm{Mn}_{0}$ & $\mathrm{Mn}_{10}$ & $\mathrm{Mn}_{100}$ & Mean \\
\hline $\mathrm{Ca}_{0}$ & 47.8 & 42.9 & 50.0 & 46.9 & 10.2 & 10.2 & 9.2 & 9.9 \\
\hline $\mathrm{Ca}_{10}$ & 84.7 & 83.7 & 66.0 & 78.1 & 11.6 & 11.7 & 10.7 & 11.3 \\
\hline Mean & 66.2 & 63.3 & 58.0 & & 10.9 & 10.9 & 10.0 & \\
\hline \multicolumn{5}{|c|}{ Phosphatase } & & & & \\
\hline Treatmen & $\mathrm{Mn}_{0}$ & $\mathrm{Mn}_{10}$ & $\mathrm{Mn}_{100}$ & Mean & & & & \\
\hline $\mathrm{Ca}_{0}$ & 7.3 & 5.9 & 4.9 & 6.0 & & & & \\
\hline $\mathrm{Ca}_{10}$ & 4.5 & 5.5 & 4.6 & 4.8 & & & & \\
\hline Mean & 5.9 & 5.7 & 4.8 & & & & & \\
\hline
\end{tabular}

${ }^{1}$ Each value represents the computed mean of 3 replicates. Sucrose is recorded as milligrams per gram of dry weight, and enzymes are expressed as specific activity (activity units per milligram of protein).

${ }_{2}$ The numerals 0,10 , and 100 with $\mathrm{Mn}$ indicate treatments of 0,10 , and 100 p.p.m., respectively. With $\mathrm{Ca}$, the numbers 0 and 10 signify treatments of 0 and 10 meq./ liter, respectively.

only when Ca was low. Since high Mn also suppressed sucrose at low-Ca levels, these findings add support to the theory that maximum sucrose formation requires a highly active amylase for destruction of polysaccharides $(4,5,8,9)$.

It is probable that $\mathrm{Ca}$ inhibition of amylase at low and medium $\mathrm{Mn}$ 
levels may represent a protective casing of the enzyme by Ca, with subsequent minimization of potential activator-inhibitor effects. Again, although 100 p.p.m. Mn is unusually high for nutrient solutions, it is evident that high Mn produces a strong calciumlike effect upon amylase

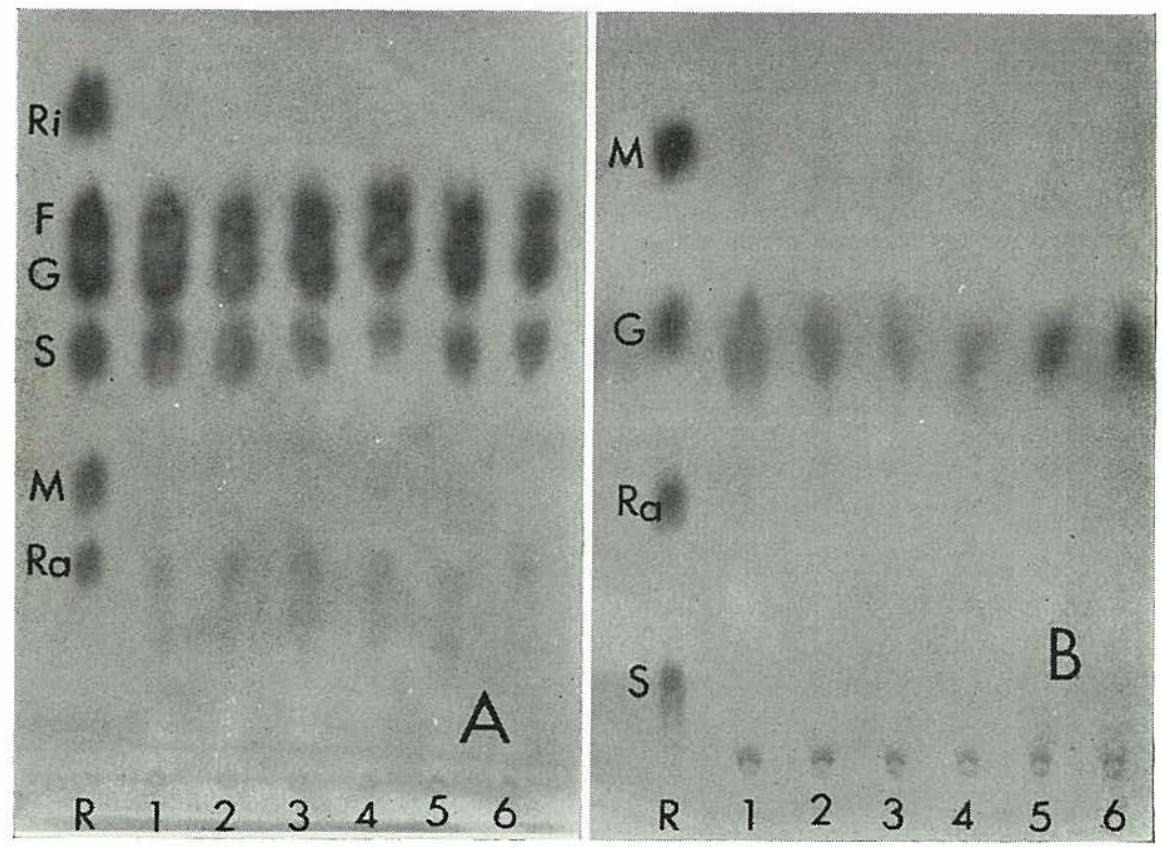

FIG. 1.-A, Paper chromatogram illustrating sugar of cane-leaf extracts derived from plants supplied with variable Ca (meq./liter) and $\mathrm{Mn}$ (p.p.m.) in sand culture. Numerals 1 through 6 represent the following treatments: $1, \mathrm{Ca}_{0} \times \mathrm{Mn}_{0} ; 2, \mathrm{Ca}_{0} \times$ $\mathrm{Mn}_{10} ; 3, \mathrm{Ca}_{0} \times \mathrm{Mn}_{100} ; 4, \mathrm{Ca}_{10} \times \mathrm{Mn}_{0} ; 5, \mathrm{Ca}_{10} \times \mathrm{Mn}_{10}$; and $6, \mathrm{Ca}_{10} \times \mathrm{Mn}_{100} ;$ letters signify the following reference sugars: $\mathrm{Ri}=$ ribose; $\mathrm{F}=$ fructose $; \mathrm{G}=$ glucose $\mathrm{S}=$ sucrose; $\mathrm{M}=$ melezitose; and $\mathrm{Ra}=$ raffinose. $\mathrm{B}$, Paper chromatogram illustrating variable glucose produced by action of amylase from plants receiving $\mathrm{Ca}$ and $\mathrm{Mn}$ in sand culture; numerals represent the same treatments listed above; the letters $M$ and $S$ represent maltose and stachyose, respectively; soluble potato starch was employed as substrate.

without increasing $\mathrm{Ca}$ content. An enzyme such as amylase might therefore provide a link between $\mathrm{Ca}$ and Mn content on one hand and sucrose content on the other.

Peroxidase was very active in high-Ca plants, as compared with those from which Ca was withheld (table 2). High Mn moderately retarded peroxidase at the high-Ca level, which verifies a similar Mn effect noted at 
different levels of silicon (23). The high peroxidase action in tissues containing less sucrose also verifies earlier observations $(2,3)$, although in vitro peroxidase experiments showed a moderate suppression of the enzyme by $\mathrm{Ca}$ (10). The relationship between peroxidase action and sucrose level remains obscure. It is suggested that this catalyst serves as a terminal oxidase in cane (2), and that it may take part in regulation of auxin level (23).

Phosphatase was inhibited by increasing $\mathrm{Mn}$ at the zero-Ca level, but Mn had no consistent effect when Ca was high. The enzyme, acting upon $\beta$-glycerophosphate, was already retarded by high $\mathrm{Ca}$, so that $\mathrm{Mn}$ in effect induced a high-Ca type of response. This again was accomplished without altering $\mathrm{Ca}$ content.

\section{EFFECTS OF CA AND MN ON NUCLEOTIDE CONSTITUENTS}

Four of the six $\mathrm{Ca} \times \mathrm{Mn}$ treatments were selected for nucleotide analysis: $\mathrm{Ca}_{0} \times \mathrm{Mn}_{0} ; \mathrm{Ca}_{0} \times \mathrm{Mn}_{100} ; \mathrm{Ca}_{10} \times \mathrm{Mn}_{0} ;$ and $\mathrm{Ca}_{10} \times \mathrm{Mn}_{100}$. Samples were taken for TCA extraction from composites of the three replicates.

Extracts passed through Dowex-1 formate invariably yielded two U.V.-absorbing peaks with $\mathrm{pH} 2.9$ formic acid-sodium formate, and a third peak when the column received $6 \mathrm{~N}$ formic acid, $\mathrm{pH} 0.6$. Analyses of peak fractions for each of the four treatments are summarized by table 3. As anticipated, most of the reducing sugar was retained in the initial U.V.-absorbing peak for each sample. By far the greatest amount was yielded by the high $\mathrm{Ca} \times$ high $\mathrm{Mn}$ sample.

Phosphorus was concentrated in the second peak of each sample, with the low $\mathrm{Ca} \times$ low $\mathrm{Mn}$ treatment predominating. It is important to note that $\mathrm{P}$ content of every third peak, that representing each treatment's highest nucleotide concentration, was more than twice as high in the low-Ca samples than in the high-Ca samples. Although table 1 indicates that total leaf $\mathrm{P}$ was not affected by Ca supply, the P from U.V.-absorbing effluents includes that retained by sugar phosphates or nucleotides before acid hydrolysis. Some of these are precursors of sucrose, such as fructose-6phosphate, glucose-1-phosphate, UDPG, etc. Their vast biochemical importance underscores a serious limitation of the total P data of plant tissues, which, in itself, tells nothing of the form assumed by $\mathrm{P}$ after absorption. We would now suspect that $\mathrm{Ca}$ has some influence over the interconversion of organic and inorganic P.

Dried chromatograms of concentrated U.V.-absorbing fractions revealed several unknown compounds when scanned with U.V. lamps. Figure 2,A illustrates fluorescent areas derived by $6 \mathrm{~N}$ formic acid elution of each $\mathrm{Ca} \times \mathrm{Mn}$ treatment sample. Of interest is the apparently low concentration of fluorescent materials from the low $\mathrm{Ca} \times$ low $\mathrm{Mn}$ samples. One of the materials is absent entirely from this treatment. Attempts to identify 
the unknown compounds were not successful. On the basis of earlier meristem studies we had anticipated adenosine, uridine, cytidine, and uracil (12), but $\mathrm{Rf}$. values for leaf constituents gave no more than tentative identification of adenosine, uridine, and cytidine.

Figure 2,B presents the two initial U.V-absorbing peaks obtained from each treatment sample and chromatographed with a series of known com-

TABLE 3.-Analytical data for peak U.V.-absorbing effluent fractions obtained by anion-exchange chromatography of sugarcane leaf preparations ${ }^{1}$

\begin{tabular}{|c|c|c|c|c|c|c|}
\hline \multicolumn{2}{|c|}{ Treatment } & \multirow{2}{*}{ U.V. Peak No. } & \multicolumn{4}{|c|}{ Data classification- } \\
\hline$\underset{\text { (meq./liter) }}{\mathrm{Ca}} \times$ & $\underset{\text { (p.p.m.) }}{\mathrm{Mn}}$ & & $\underset{\text { sugar }^{2}}{\text { Total }}$ & $\underset{\mathrm{P}^{3}}{\text { Total }}$ & $\begin{array}{c}\text { Total } \\
\text { nucleotide }\end{array}$ & $\frac{E_{275}}{E_{260}}$ \\
\hline \multirow[t]{3}{*}{0} & 0 & 1 & 6.00 & 40 & 3.2 & 0.86 \\
\hline & & 2 & 1.14 & 680 & 3.6 & .88 \\
\hline & & 3 & 1.18 & 104 & 63.2 & 1.04 \\
\hline \multirow[t]{3}{*}{0} & 100 & 1 & 5 & 5 & 2.7 & .83 \\
\hline & & 2 & 5 & 5 & 4.1 & .78 \\
\hline & & 3 & 1.14 & 98 & 66.0 & 1.03 \\
\hline \multirow[t]{3}{*}{10} & 0 & 1 & 2.88 & 60 & 2.2 & .80 \\
\hline & & 2 & 1.18 & 480 & 4.2 & .78 \\
\hline & & 3 & 1.16 & 44 & 53.6 & 1.03 \\
\hline \multirow[t]{3}{*}{10} & 100 & 1 & 11.50 & 50 & 2.7 & .67 \\
\hline & & 2 & 1.58 & 420 & 4.1 & .69 \\
\hline & & 3 & 1.06 & 43 & 63.0 & 1.03 \\
\hline
\end{tabular}

1 The sugarcane had been supplied with variable Ca and $\mathrm{Mn}$ in sand culture. All analyses were conducted with the milliliter giving maximum absorption at $260 \mathrm{~m} \mu$ within each peak.

${ }^{2}$ Milligrams/milliliter.

${ }^{3}$ Milligrams $\times 10^{3}$ per milliliter.

${ }^{4}$ O.D.260 units.

${ }^{5}$ Data not available.

pounds. Samples from each of the three illustrated treatments contained a pair of strongly fluorescent compounds which almost superimposed upon one another. Of particular interest was a third fluorescing substance of varying spot size and mobility (spots a, b, and c). Component a, least mobile and most difficult of the three to detect, was produced in the low$\mathrm{Ca} \times$ low-Mn plants, whereas component $\mathrm{c}$, extracted from high $\mathrm{Ca} \times$ high-Mn plants was highly mobile and presented a large, vivid spot. Very likely a single compound, perhaps a free base, is represented in varying combination with $\mathrm{Ca}$ or $\mathrm{Mn}$, or in combination with unknown products 
of the different nutritional regimes. The compounds seemingly superimposed are apparently the monophosphates of adenosine, cytidine, or glucose. The mobile compound (a,b,c) is possibly glucoseamine.

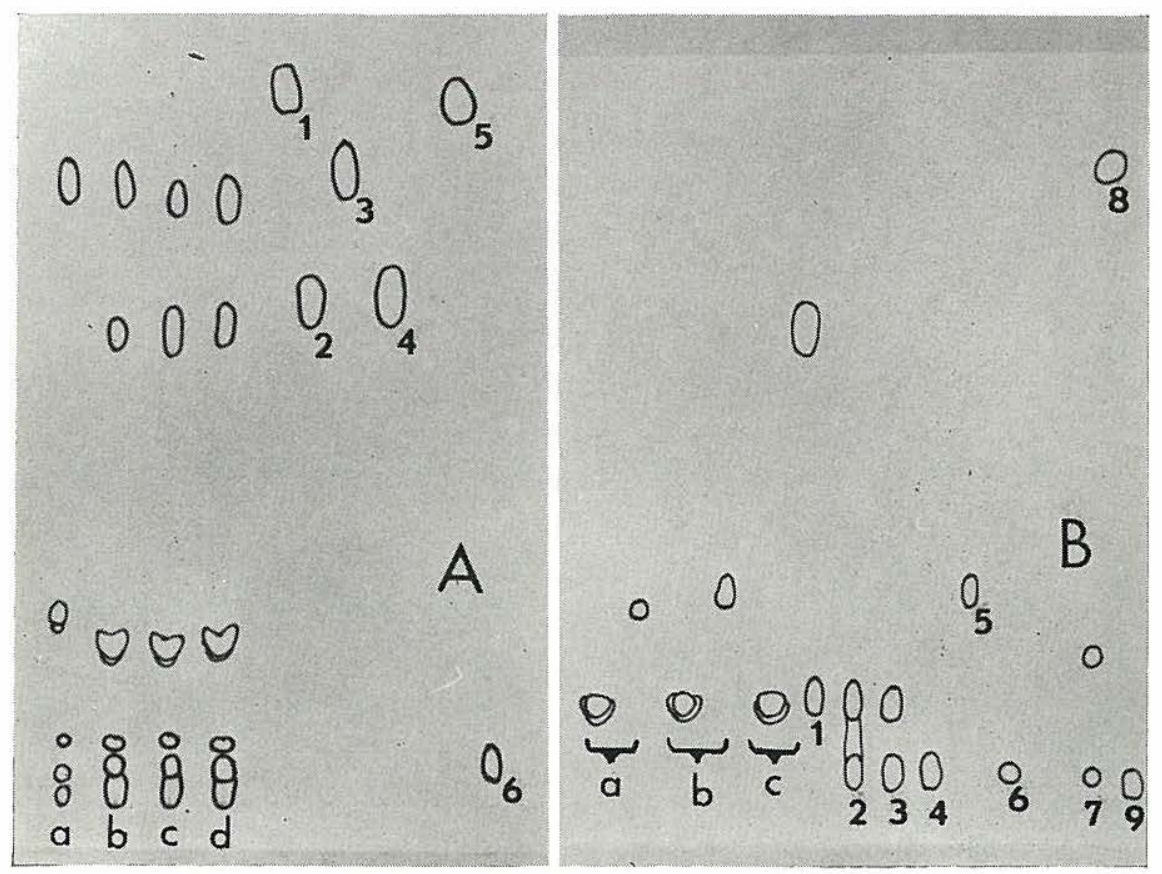

FIG. 2.-A, Paper chromatogram illustrating size and position of fluorescent spots which represent U.V.-absorbing materials of cane leaves; the plants had been subjected to variable $\mathrm{Ca}$ (meq./liter) and $\mathrm{Mn}$ (p.p.m.) in sand culture; small letters stand for $6 \mathrm{~N}$ formic acid elutions from anion-exchange columns, with treatments represented as follows: a, $\mathrm{Ca}_{0} \times \mathrm{Mn}_{0} ; \mathrm{b}, \mathrm{Ca}_{0} \times \mathrm{Mn}_{100} ; \mathrm{c}, \mathrm{Ca}_{10} \times \mathrm{Mn}_{0} ;$ and $\mathrm{d}, \mathrm{Ca}_{10} \times \mathrm{Mn}_{100}$. Numbers signify the following reference compounds: $1=$ uridine; $2=$ adenosine; $3=$ cytidine; $4=$ uracil $5=$ xanthine; and $6=$ UDPG. B, Paper chromatogram illustrating fluorescent compounds obtained from cane leaves; each small letter stands for the initial pair of U.V.-absorbing peaks obtained with formic acid-sodium formate from anion-exchange columns, with treatments represented as follows: a, $\mathrm{Ca}_{0} \times \mathrm{Mn}_{0}$; $\mathrm{b}, \mathrm{Ca}_{10} \times \mathrm{Mn}_{0}$; and $\mathrm{c}, \mathrm{Ca}_{10} \times \mathrm{Mn}_{100}$. Numbers signify the following reference compounds: 1 = adenosine monophosphate; 2 = cytidine monophosphate; $3=$ glucose monophosphate; $4=$ uridine monophosphate; $5=$ glucoseamine; $6=$ deoxyribose nucleic acid; $7=$ flavin adenine dinucleotide; $8=$ xanthine; and $9=$ diphosphopyridine nucleotide.

Sugar components of peak U.V.-absorbing fractions were chromatographed with butanol-pyridine-water, dried, and stained. Figure 3 illustrates a typical chromatogram of sugars obtained from resin columns with 
formic acid-sodium formate, plus several reference sugars commonly found in plants. From two to six distinct compounds were obviously present within each of the peak fractions. Several features are immediately evident, including at least two sugars present in the low-Ca $\times$ low-Mn peaks (No. 1) which are absent from the high-Ca $\times$ low-Mn peaks (No. 2). Considerably more sugar was present in the low-Ca sample as evidenced

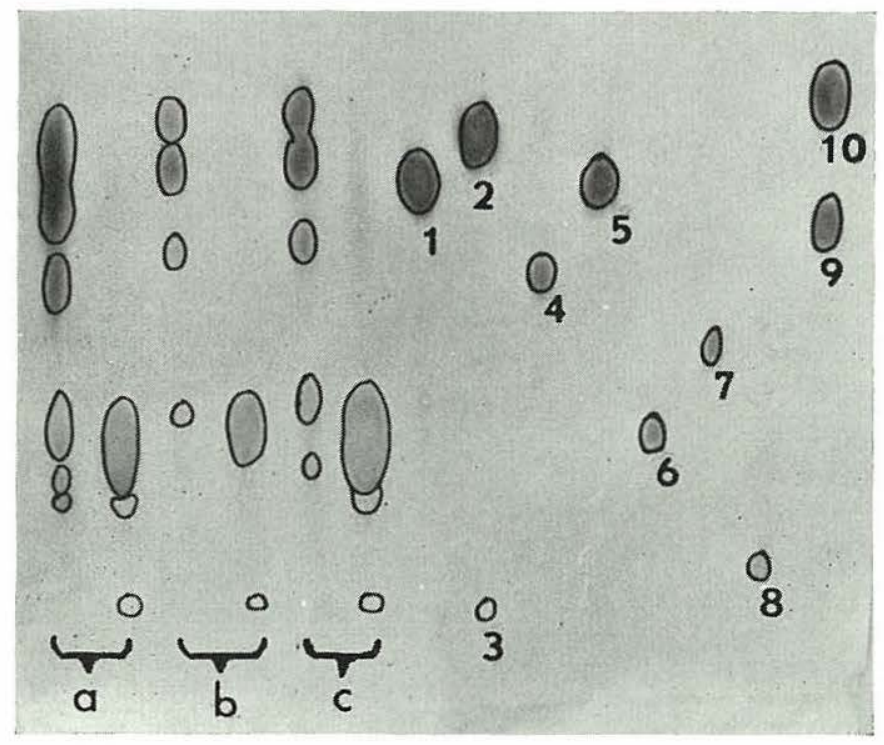

FIG. 3.-Paper chromatogram illustrating sugar constituents of U.V.-absorbing preparations from sugarcane supplied with variable Ca and Mn in sand culture. Each small letter represents the initial pair (peak Nos. 1 and 2) of U.V.-absorbing peaks eluted from anion-exchange columns with formic acid-sodium formate; treatments are as follows: a, $\mathrm{Ca}_{0} \times \mathrm{Mn}_{0}$; b, $\mathrm{Ca}_{10} \times \mathrm{Mn}_{0}$; and $\mathrm{Ca}_{10} \times \mathrm{Mn}_{100}$. Numerals signify the following reference sugars: $1=$ Glucoseamine; $2=$ maltose; $3=$ UDPG; $4=$ glucose $5=$ galactose $6=$ raffinose $; 7=$ melezitose $; 8=$ stachyose $; 9=$ turanose; and $10=$ fructose.

by the relatively broad and heavy stains. Yet when both Ca and Mn were high (No. 3), one of the deleted sugars reappeared in conjunction with generally increased sugar content.

Specific identification was difficult, but the sugars glucose, maltose, and raffinose appeared in all treatment samples. In addition, peak fractions of sample No. 1 (low $\mathrm{Ca} \times$ low $\mathrm{Mn}$ ) apparently include glucoseamine and turanose. Two sugars appeared in effluents derived by $6 \mathrm{~N}$ formic acid elution (not shown), one of which was identified as raffinose. The full significance of the sugar and nucleotide variations is not yet understood. 
Undoubtedly some of these play important roles in sucrose production. In any event it is important to recognize the capacity for Ca and $\mathrm{Mn}$ to alter their number and content.

\section{SUMMARY}

Immature sugarcane was subjected to variable calcium (Ca) and manganese $(\mathrm{Mn})$ in sand culture. Two levels of $\mathrm{Ca}$ were provided in factorial combination with three levels of $\mathrm{Mn}$. Leaf samples were harvested for analysis after 3 months of treatment. There were three objectives: 1, To determine whether Ca could modify the rate of Mn uptake; 2, to determine main effects and interactions of $\mathrm{Ca}$ and $\mathrm{Mn}$ on specific enzymes; and 3, to study $\mathrm{Ca}$ and $\mathrm{Mn}$ effects on sugar and nucleotide content of leaves. The following results were obtained:

1. High Ca, 10 meq./liter, enhanced Mn uptake rather than cause Mn suppression.

2. Silicon content was decreased by high Mn (100 p.p.m.), but only when $\mathrm{Ca}$ was low. Ca thus is able to interfere with the $\mathrm{Mn} \times \mathrm{Si}$ interaction by which increasing Mn supply decreases Si uptake.

3. Leaf sucrose content was generally higher among plants receiving low Ca. This verifies observations by other workers.

4. High Mn appeared to substitute for high $\mathrm{Ca}$ in its influence upon sucrose content and amylase activity. A high-Ca effect upon amylase is induced by $\mathrm{Mn}$ without increasing $\mathrm{Ca}$ content.

5. High Mn greatly retarded amylase action when Ca supply was low, but had no effect when Ca supply was high.

6. Peroxidase action was relatively high among plants containing less sucrose, verifying earlier observations at this laboratory. High Ca greatly stimulated the enzyme.

7. Content of acid-soluble nucleotides did not vary greatly among treatments. Reducing sugar and total phosphorus content of nucleotide preparations varied strikingly. Sugar content was greatest in preparations from plants receiving both high $\mathrm{Ca}$ and high $\mathrm{Mn}$. More than twice as much phosphorus was found in hydrolyzed, low-Ca nucleotide preparations than was present in those of plants receiving high $\mathrm{Ca}$. Ca thus appears to affect the interconversion of organic and inorganic phosphorus.

8. Both $\mathrm{Ca}$ and $\mathrm{Mn}$ affected the number, concentration, and paper chromatographic properties of unknown fluorescing constituents obtained by anion-exchange chromatography. Adenosine, uridine, cytidine, and glucoseamine were tentatively identified.

9. Paper chromatograms revealed that the sugars glucose, maltose, and raffinose appeared in all peak U.V.-absorbing fractions. Glucoseamine and 
turanose were apparently present only in plants receiving both low $\mathrm{Ca}$ and low Mn.

Results of this study suggest that Ca interacts with Mn in mineral absorption and enzyme effects, that $\mathrm{Ca}$ can alter known $\mathrm{Mn} \times \mathrm{Si}$ relationships, and that the consequences of variable $\mathrm{Ca}$ and $\mathrm{Mn}$ content are felt by the plant over a broad range of biochemical reactions.

\section{RESUMEN}

Plantas inmaduras de caña de azúcar cultivadas en arena se sometieron a tratamientos variables de calcio (Ca) y manganeso (Mn). Se usaron dos niveles de $\mathrm{Ca}$ en un tratamiento combinado con tres niveles de $\mathrm{Mn}$. Después de 3 meses de tratamiento se tomaron muestras de las hojas para analizarse. Tres fueron los propósitos del análisis: 1, Determinar si el Ca podía modificar el ritmo de absorción del Mn por la planta; 2, determinar los efectos e interacciones principales del Ca y el Mn sobre ciertas enzimas específicas; y 3, estudiar los efectos del Ca y el Mn sobre el contenido de azúcares y nucleótidos en la hoja. Los resultados fueron los siguientes:

1. Un alto nivel de $\mathrm{Ca}$ (10 miliequivalentes por litro) aceleró la absorción del Mn más bien que suprimirla.

2. El contenido de silicio disminuyó al aplicarse un alto nivel de Mn (100 partes por millón), pero sólo cuando el nivel de Ca era bajo. De modo que el Ca puede interponerse en una interacción de $\mathrm{Mn} \times \mathrm{Si}$ ya establecida en la que al aumentarse el Mn disminuye la absorción del Si.

3. El contenido de azúcar en la hoja generalmente aumentó en las plantas que recibieron poco Ca. Esto confirma las observaciones hechas por otros investigadores.

4. Un alto nivel de Mn aparentemente puede sustituir un alto nivel de $\mathrm{Ca}$ en cuanto a su efecto sobre el contenido de la sacarosa y la actividad de la amilasa. El Mn produce el mismo efecto de un alto nivel de Ca sobre la amilasa sin aumentar el contenido de Ca.

5. El Mn aplicado a un alto nivel demoró grandemente la acción de la amilasa cuando el suministro de Ca fue bajo, pero no tuvo efecto alguno cuando el suministro de $\mathrm{Ca}$ fue alto.

6. La acción de la peroxidasa fue relativamente intensa en las plantas que contenían poca sacarosa, confirmando las observaciones previas hechas en este laboratorio. El Ca a niveles altos estimuló grandemente la enzima.

7. El contenido de nucleótidos ácidosolubles no varió marcademente entre los tratamientos. Los azúcares reductores y el contenido total de fósforo en preparaciones de nucleótidos variaron notablemente.

El contenido de azúcar fue mayor en las preparaciones de aquellas plantas que recibieron altos niveles de $\mathrm{Ca}$ y $\mathrm{Mn}$. En las preparaciones 
hidrolizadas de nucleótidos, bajas en calcio, se encontró más del doble de la cantidad de fósforo que en las plantas que recibieron un alto nivel de Ca. El Ca aparentemente afecta la interconversión de fósforo orgánico e inorgánico.

8. Tanto el Ca como el Mn afectaron el número, la concentración y las propiedades en papel cromatográfico de constituyentes fluorescentes desconocidos que se obtuvieron mediante la cromatografía de intercambio aniónico. La adenosina, la uridina, la citidina y la glucosamina se identificaron tentativamente.

Cromatogramas en papel revelaron que azúcares tales como la glucosa, maltosa y rafinosa aparecieron en todos los puntos cimeros de las fracciones de absorción ultravioleta. Aparentemente la glucosamina y la turanosa sólo se encontraban en las plantas que recibieron tratamientos bajos en Ca y Mn.

Los resultados de este estudio sugieren que existe una interacción entre el Ca y el Mn, en la absorción de minerales y en su efecto sobre las enzimas, que el Ca puede alterar las relaciones conocidas del $\mathrm{Mn} \times \mathrm{Si}$, y que las consecuencias que puedan resultar de los contenidos variables de Ca y Mn se manifiestan en la planta en una amplia serie de reacciones bioquímicas.

\section{LITERATURE CITED}

1. Abruña, F., Vicente-Chandler, J., and Pearson, R. W., Effect of liming on yields and composition of heavily fertilized grasses on soil properties under humid tropical conditions, Soil Sci. Soc. Amer. Proc. 28: 657-61, 1964.

2. Alexander, A. G., Sucrose-enzyme relationships in immature sugarcane as affected by varying levels of nitrate and potassium supplied in sand culture, J. Agr. Univ. P.R. 48 (3): 165-231, 1964.

3. - Changes in leaf-sugar content and enzyme activity of immature sugareane following foliar application of indole-3-acetic acid, 2,4-dichlorophenoxy-acetic acid, and maleic hydrazide, J. Agr. Univ. P.R. 49 (1): 1-34, 1965.

4. - Physiological studies of enzymes catalyzing the synthesis and hydrolysis of sucrose, starch, and phosphorylated hexose in sugarcane, J. Agr. Univ. P.R. 49 (1): 60-75, 1965.

5. - Behavior of enzymes governing starch- and sucrose-forming pathways in two sugarcane varieties supplied with variable nitrate and phosphate in sand culture, J. Agr. Univ. P.R. 49 (2): 153-75, 1965.

6. - Induction of varying sugar levels in leaves of immature sugarcane by use of acid phosphatase inhibitors, J. Agr. Univ. P.R. 49 (1): 35-59, 1965.

7. - - Hydrolytic proteins of sugarcane: The acid invertases, J. Agr. Univ. P.R. 49 (3): 308-24, 1965.

8. - Hydrolytic proteins of sugarcane: Amylase, J. Agr. Univ. P.R. 49 (3): 308-24, 1965.

9. - - The biosynthesis of starch in sugarcane, Proc. Int. Soc. Sugarcane Tech., 12th Cong., San Juan, P.R. 1965 (in press). 
10. - The oxidizing enzymes of sugarcane: Peroxidase, J. Agr. Univ. P.R. 50 (1): 36-52, 1966.

11. - The oxidizing enzymes of sugarcane: Tyrosinase, J. Agr. Univ. P.R. 50 (2): 113-30, 1966.

12. — - Nucleotides of sugarcane: TCA-soluble and protein-bound nucleotides of sugarcane meristem, J. Agr. Univ. P.R., 51 (3): (210-27, 1967).

13. - - Nucleotides of sugarcane: Increased nucleotide content of leaves as a function of nutritional stress, J. Agr. Univ. P.R. (in press).

14. - High sucrose levels and abnormal enzyme activity as a function of nutritional stress in sugarcane, J. Agr. Univ. P.R. (in press).

15. Bonnet, J. A., Lugo-López, M. A., Roldán, J., and Pérez-Escolar, R., Effect of lime and phosphate-bearing materials on sugarcane yields, J. Agr. Univ. P.R. 42 (1): 1-6, 1958.

16. Cardini, C. E., Leloir, L. F., and Chiriboga, J., The biosynthesis of sucrose, $J$. Biol. Chem. 214: 149-55, 1955.

17. Clements, H. F., Effects of silicate on the growth and leaf freckle of sugarcane, Proc. Int. Soc. Sugarcane Tech., 12th Cong., 1965 (in press).

18. Dube, S. K., and Nordin, P., Isolation and properties of sorghum alpha-amylase, Arch. Biochem. and Biophys. 94: 121-7, 1961.

19. Hurlbert, R. B., Schmitz, H., Brumm, A. F., and Potter, V. R., Nucleotide metabolism, II, Chromatographic separation of acid-soluble nucleotides, J. Biol. Chem. 209: 23-39, 1954.

20. Landrau, P., and Samuels, G., Results of lime and minor element fertilizer research in Puerto Rico, 1949-50, J. Agr. Univ. P.R. 40 (4): 223-34, 1956.

21. Methods of Analysis of the Association of Official Agricultural Chemist, 6th ed., Washington, D.C., pp. 127-8, 1945.

22. Samuels, G., and Cibes, H., Influence of mineral deficiencies on the growth and yield of sugarcane, J. Agr. Univ. P.R. 47 (2): 61-75, 1963.

23. Samuels, G., and Alexander, A. G., Influence of variable manganese and silicon on the nutrition, sugar production, and enzyme activity of immature sugarcane, Proc. Int. Soc. Sugar Cane Technol. (Submitted, 1968 Cong.)

24. Sumner, J. B., Dinitrosalicylic acid, a reagent for the estimation of sugar in normal and diabetic urine, J. Biol. Chem. 47: 5-9, 1921.

25. Sutherland, E. W., Cori, C. F., Haynes, R., and Olsen, N. S., Purification of the hyperglycemic-glycogenolytic factor from insulin and from gastric mucosa, J. Biol. Chem. 180: 825-37, 1949.

26. Villiens de, and O. D. Hotman, Soil rejuvenation with crushed basalt in Mauritius, I, Int. Sugar J. 6s: 363-4, 1961. 